\title{
Designing for international law: The architecture of international organizations 1922-1952
}

\author{
Miriam Bak McKenna*(i) \\ Lund University, Faculty of Law, Lilla Gråbrödersgatan 4, 22222 Lund, Sweden \\ Email: Miriam.mckenna@jur.lu.se
}

\begin{abstract}
Situating itself in current debates over the international legal archive, this article delves into the material and conceptual implications of architecture for international law. To do so I trace the architectural developments of international law's organizational and administrative spaces during the early to mid twentieth century. These architectural endeavours unfolded in three main stages: the years 1922-1926, during which the International Labour Organization (ILO) building, the first building exclusively designed for an international organization was constructed; the years 1927-1937 which saw the great polemic between modernist and classical architects over the building of the Palace of Nations; and the years 1947-1952, with the triumph of modernism, represented by the UN Headquarters in New York. These events provide an illuminating allegorical insight into the physical manifestation, modes of self-expression, and transformation of international law during this era, particularly the relationship between international law and the function and role of international organizations.
\end{abstract}

Keywords: architecture; historiography; international law; law and aesthetics; legal materiality

\section{Introduction}

'When we make a building for the UN', noted Oscar Niemeyer in 1947,

we must have in mind what is the UN? It is an organization to set the nations of the world in a common direction and gives to the world security. I think it is difficult to get this into steel and stone. But if we make something representing the true spirit of our age, of comprehension and solidarity, it will by its own strength give the idea that that is the big political effort, too. ${ }^{1}$

Niemeyer had just embarked on one of the most ambitious architectural projects of the post-war era, the construction of the United Nations Headquarters in New York, but his comments highlighted a development that had been underway for some decades - the relationship between architectural design and international law. From the interwar period onwards, the gradual institutionalization of international law was to alter the very telos of the international order and lead to

${ }^{\star}$ I would like to thank the friends and colleagues whose comments and encouragement contributed to this project, particularly Morten Bak. I am also grateful to the participants of the Art and International Courts Workshop held by the Art and International Justice Initiative at The University of Copenhagen and the Critical Research in International Law workshop held at The Erik Castrén Institute for their helpful feedback and comments. All ideas and errors are all my own.

${ }^{1}$ Quoted in 'Oscar Niemeyer and the United Nations Headquarters', UN Archives, available at archives.un.org/content/ oscar-niemeyer-and-united-nations-headquarters.

(C) The Author(s), 2020. Published by Cambridge University Press. This is an Open Access article, distributed under the terms of the Creative Commons Attribution licence (http://creativecommons.org/licenses/by/4.0/), which permits unrestricted re-use, distribution, and reproduction in any medium, provided the original work is properly cited. 
the establishment of a number of permanent international organizations. ${ }^{2}$ The structures that would house these organizations were the spaces in which international law and politics were to literally take shape and were to serve as functional and symbolic metaphors for a new era of international legal and political co-operation. Yet efforts to develop an architectural expression as a means of communicating the existence of a supra-national community, indeed of navigating the fraught nature of internationalism itself, was to prove a highly controversial endeavour. ${ }^{3}$

Situating itself in current debates over the international legal archive and where - in which sites, spaces and objects - we can apprehend the history of international law, this article delves into the material and conceptual implications of architecture for international law. 'To understand law's contemporary function as a vernacular of political judgement, we need to pay particular attention to changes in ideas about law', stresses David Kennedy. ${ }^{4}$ In a similar vein, this article seeks to trace the representation and reproduction of images of international law by unravelling the connections between architectural style and broader patterns of international legal and political change. It is argued that the physical architecture of the buildings that house international legal organizations is - or should be - of interest to international lawyers, not just architects or architectural historians. This is because these buildings relate in important ways to international legal and political culture. ${ }^{5}$ It is my claim that the sites and spaces of international law (courts, organization buildings, offices etc.) create law's physical presence, generating the material space in which international law is practiced, and in which ideas about international law and the identity of the international legal community can be expressed and, more importantly, experienced. ${ }^{6}$ This is true, I argue, not only of their functional aspects (the spatial elements that support the operation of international law) but also their aesthetic qualities. ${ }^{7}$ Through their design, buildings can communicate a visual identity, forming and projecting a range of institutional ideals, functions, and values. ${ }^{8}$ They are also spaces which greatly influence the social function and individual experience of international law, particularly as it is expressed to an imagined community. ${ }^{9}$ Many of the spatial practices adopted in the legal spaces and courts of international law evolved in very different social and political contexts, and project radically different ideas about international law, but are rarely subjected to sustained critique. This article reflects on the impact of international law and vice versa on architectural design and aesthetics, the aims and politics underlying their construction, and the involvement and impact of various political and social actors in their construction.

To do so I trace the architectural developments of international law's organizational and administrative spaces during the early to mid twentieth century. As international organizations

\footnotetext{
${ }^{2}$ See G. Sluga, Internationalism in the Age of Nationalism (2013).

${ }^{3}$ See Mark Crinson's masterful investigation of the link between modern architecture and internationalism. M. Crinson, Rebuilding Babel: Modern Architecture and Internationalism (2017), 9-15.

${ }^{4}$ D. Kennedy, Of War and Law (2006), 46.

${ }^{5}$ T. Gieryn, 'What Buildings Do', (2002) 31(1) Theory and Society 35; H. Y. Kang, 'Law's Materiality: Between Concrete Matters and Abstract Forms, or How Matter Becomes Material', in A. Philippopoulos-Mihalopoulos (ed.), Routledge Handbook of Law and Theory (2018), 453; H. Gurdalli and U. Koldas, 'Architecture of Power and Urban Space in a Divided City: A History of Official Buildings in Nicosia/Lefkosa', (2015) 18(1) The Design Journal 135.

${ }^{6}$ See S. Stolk and R. Vos, 'International Legal Sightseeing', (2018) 2 Journal of the Oxford Centre for Socio-Legal Studies; H. Y. Kang, 'Law's Materiality: Between Concrete Matters and Abstract Forms, or How Matter Becomes Material', in Philippopoulos-Mihalopoulos, ibid., at 453; C. Hutton, 'Linguistic Landscape, Law and Reflexive Modernity', in A. Wagner and R. K. Sherwin (eds.), Law, Culture and Visual Studies (2014), 599.

${ }^{7}$ On the significance of visual narratives and image-making to international law see also D. Joyce, 'Photography and the Image-making of International Justice', (2010) 4(2) Law and Humanities 229.

${ }^{8}$ See A. Tait, 'What We Didn't See Before', (2012) 24 Yale Journal of Law \& Humanities; S. Stolk and R. Vos, 'Law in Concrete: Institutional Architecture in Brussels and The Hague', (2020) 14(1) Law and Humanities; M. Bak McKenna “'A Happy Building": Architecture and Universal Justice at the International Criminal Court', Art and International Justice Initiative, 28 June 2019, available at artij.org/en/blog.html\#9.

${ }^{9}$ R. Moore, Why We Build (2012). See also M. Kretzer, 'Information Materials': Smart Materials for Adaptive Architecture (2017).
} 
have come to occupy a dynamic space at the intersection of international law and international politics, as both facilitators of international law and promoters of international polity, ${ }^{10}$ their design and development (particularly in architectural terms) have been highly influential in framing international law's imaginaries. These architectural endeavours unfolded in three main stages: the years 1922-1926, during which the ILO building, the first building exclusively designed for an international organization was constructed; the years 1927-1937 which gave rise to the great debate between modernist and classical architects over the building of the Palace of Nations; and the years 1947-1952, with the triumph of modernism, represented by the UN Headquarters in New York. These events provide an illuminating allegorical insight into the physical expression and transformation of international law during this era, particularly the relationship between international law and the function and role of international organizations. As multiple actors sought quite literally and metaphorically to construct a new international legal order, these 'well-ventilated utopias'11 serve as monuments to the broader battles over international law during the first half of the twentieth century.

The construction of the Palace of Labour and the Palace of Nations in Geneva coincided with what Kennedy calls the height of state-centric positivism emerging at the beginning of the twentieth century 'contemporaneous with the most insistent calls for modernization of the field'. ${ }^{12}$ During the construction of these structures, the friction between the old-world order and modernist aspirations reflected the fierce debates over the compatibility of membership in international organizations with state sovereignty and which form and content the international legal order should assume, along with the patterns of power and influence underpinning this aesthetic struggle. ${ }^{13}$ Ultimately, conventional architecture which elevated nineteenth century neo-classical and pan-European nationalist expressions of political power, was to be closely linked to the creation of the League of Nations; a result that seemed to seal the fate of the doomed League system. Later the idealistic desire for international unity expressed on a political level in the founding of the United Nations was at the same time manifest in the aesthetic discourse of the 'boundary-less' modernist expression, dubbed the International Style, which was represented by Niemeyer and Le Corbusier's modernist vision for the UN Headquarters in New York. However, modernism's utopian attempts at mediating between the values of localism and universalism were to be equally as fraught. While little attention has been paid to these issues, I will argue that the conflicting aspirations and anxieties that animated the design process and their legacy for the international legal project remain with us.

In focusing on the architectural representation of these international legal bodies in this article, I am making a number of broader arguments about how we might view international law and its history. The first concerns the increasingly central role processes of international legal reproduction - the means and process by which international law constitutes itself and its subjects - have on our understanding of the field of international law. ${ }^{14}$ As a rich body of critical legal thought has underlined, international law has been driven by the emergence and consolidation of a particular mode of legal organization, which is both historically and geographically contingent. ${ }^{15}$ In focusing

\footnotetext{
${ }^{10}$ See also A. Peters, 'International Organizations and International Law', in J. Cogan, I. Hurd and I. Johnstone (eds.), Oxford Handbook of International Organizations (2016), 34.

${ }^{11}$ The term 'well-ventilated utopias' was coined by Walter Benjamin to describe the revolutionary structures of modernism. W. Benjamin, 'Surrealism: The Last Snapshot of the European Intelligentsia', in M. W. Jennings, H. Eiland and G. Smith (eds.), Walter Benjamin, Selected Writings, Vol. 2 (1999), at 209.

${ }^{12}$ D. Kennedy, 'International Law and the Nineteenth Century: History of an Illusion', (1997) 99(17) Quinnipiac L Rev 101, at 103 .

${ }^{13}$ See J. Klabbers, An Introduction to International Institutional Law (2015).

${ }^{14}$ See, e.g., R. Parfitt, The Process of International Legal Reproduction (2019).

${ }^{15}$ See B. S. Chimni, International Law and World Order: A Critique of Contemporary Approaches (2017); A. Anghie, Imperialism, Sovereignty and the Making of International Law (2004); G. Simpson, Great Powers and Outlaw States: Unequal Sovereigns in the International Legal Order (2004); S. Kendall, "Cartographies of the Present: "Contingent Sovereignty” and Territorial Integrity', in M. Kuijer and W. Werner (eds.), (2016) 47 Netherlands Yearbook of International Law 83, at 100.
} 
on the contestations over modes of aesthetic representation in international law, and the various strategies and devices employed to both manifest and demarcate imaginations of the discipline, I am alluding to a construction of international law not as some fixed idea or settled definition, but rather a constellation of references and possibilities. ${ }^{16}$ Just as Patricia Clavin asserts that there was no 'single League of Nations at Geneva', these architectural developments point to the fact that there was no one single or representative perspective on what the international legal order was said to embody. ${ }^{17}$ This fact is illustrated quite neatly by the aesthetic diversity of the nearly 400 entries submitted to the competition to design the League of Nations building. Yet, these iconic buildings and their aesthetic expressions have assumed a very powerful and symbolic role in what we associate international law and its values to be. Our tendency not to submit these symbolic associations to critique (for example, how the design, organization, and location of the Peace Palace influences our understanding of international law), and to naturalize certain forms of seeing without questioning why and how these have come to dominate is the overarching aim of this project.

Approaching the history of international law through an architectural lens is both an invitation to reconsider the normative orientation of international legal study - one which reconsiders the sources and sites of international law - and the empirical materials engaged. In this sense, this article also seeks to connect with broader debates surrounding the history and historiography of international law, ${ }^{18}$ as well as efforts to open the artefactual archive of international law in order to offer alternative visions of what international law is. ${ }^{19}$ Efforts by this scholarship to address how international law is 'placed' in the world and the symbolic claims it makes to power and authority through material things have produced new insights into the impact of law on social realities. ${ }^{20}$ Seeking to examine law beyond the perimeter of legal texts (treaties, cases, textbooks, journals, and other academic writings), not only situates the law in a wider material and political context, but profoundly disrupts the positivist concept of the law as immaterial, universal and abstract, allowing us to explore new angles on what international law is as an entity, and what it is intended to project as an idea. $^{21}$

In what follows I explore three different architectural episodes which throw new light upon the historical processes of international institutionalization, and the changing character and image of international law these buildings reflected. It is far from an even-handed survey, including only

\footnotetext{
${ }^{16}$ See N. Rajkovic, 'On Fragments and Geometry: The International Legal Order as Metaphor and How it Matters', (2013) Erasmus Law Review 6.

${ }^{17}$ P. Clavin, Securing the World Economy: Reinvention of the League of Nations 1920-1946 (2013), at 7. See also D. Laqua (ed.), Internationalism Reconfigured Transnational Ideas and Movements between the World Wars (2011).

${ }^{18}$ See, e.g., M. Craven, 'Introduction: International Law and Its Histories', in M. Craven, M. Fitzmaurice and M. Vogiatzi (eds.), Time, History and International Law (2007), 1; R. Lesaffer, 'International Law and its History: The Story of an Unrequited Love', in, ibid., at 27; M. Koskenniemi, 'A History of International Law Histories', in B. Fassbender and A. Peters (eds.), The Oxford Handbook of the History of International Law (2012), 943.

${ }^{19}$ See M. Chiam et al., 'The History, Anthropology and the Archive of International Law Project', (2017) 5 London Review of International Law 1.

${ }^{20}$ See, e.g., M. Foucault, Discipline and Punish: The Birth of the Prison (1977); D. Harvey, Justice, Nature and the Geography of Difference (1996); L. Fairweather and S. McConville (eds.), Prison Architecture: Policy, Design and Experience (2000); N. Blomley, D. Delaney and R. Ford (eds.) The Legal Geographies Reader (2001). On the material dimension of law see, e.g., A. Hunt, Explorations in Law and Society: Towards a Constitutive Theory of Law (1993); A. Pottage and M. Mundy (eds.), Law, Anthropology and the Constitution of the Social: Making Persons and Things (2004); J. Brigham, Material Law: A Jurisprudence of What's Real (2009); L. Eslava, Local Space, Global Life: The Everyday Operation of International Law and Development (2015).

${ }^{21}$ See R. Parfitt, 'The Spectre of Sources', (2014) 25 European Journal of International Law 297. See also S. B. Kirmse, 'Sleepy Side Alleys, Dead Ends, and the Perpetuation of Eurocentrism', (2014) 25 European Journal of International Law 307.
} 
three main sites by way of comparison, and all in a Western setting. ${ }^{22}$ It must also be said that the story I present here - one that focuses on the frictions over the symbolic presence international law and power as projected through architecture, and specifically on the tensions between modernist vs classical representations of power, is only one of a multitude of interpretations and parallel histories related to international law contained within these structures. Adopting a feminist lens, for example, one could examine the gendered dynamics inherent in these buildings, perhaps reflecting not only the assumed identity of a male diplomat, but also the make-up of the all-male design teams. ${ }^{23}$ Or by broadening or narrowing my selection either geographically or numerically, for example, by comparing the Arab League building with the United Nations Headquarters, I could tell a very different story about different visions of internationalism. In this article, I have chosen these structures in order to tell a story of the anxieties and ambivalences that were provoked during a period of convergence between modernist and internationalist trends both politically and architecturally, and how these were manifested in the search to define the role and function of international organizations, and international law and order more generally, against a changing political and legal backdrop. My overall aim with this brief, and somewhat limited, historical overture is to provide some groundwork for future study of international law and architecture, by delving into how international law shapes our surrounding realities, and what insights can be garnered from a reading of the international legal order through architecture. Therefore, to begin with, I present the case for an architectural reading of international law's history, and its critical potential in offering deeper insights into the history of international law.

\section{Architecture and expressions of international legal identity}

Architecture synthesizes both artefact and place-making and for this reason it provides a unique historical record. ${ }^{24}$ While architecture is only one aspect of the way in which power operates spatially, it is nevertheless uniquely reflective of particular attitudes, cultural practices and ideologies, and of strategies for staging and encoding that power onto physical space. ${ }^{25}$ Moreover, by virtue of its patronage and resource requirements, it provides a commentary on certain social, political, and cultural struggles within a society. The practice of architecture as an 'aesthetic act' in Jacques Ranciere's terminology is revealing of a particular subjectivity, especially in relation to questions of legal and political identity - of what matters and what counts. ${ }^{26}$ As Nikolas Kretzer explains: 'the role and importance of buildings includes much more than structural properties but equally informs a subject's experience of a building through its aesthetic, visual and haptic qualities, as well as its associated political, social, cultural and historical meaning. ${ }^{27}$

As many scholars have underlined, law remains deeply integrated with aesthetic principles and grounded in the rhetoric of the image. ${ }^{28}$ This is evident from the iconographic and architectural forms that continue to characterize the legal environment, for example, through the tropes and

\footnotetext{
${ }^{22}$ In many ways this is unavoidable as Europe remained the centre of activities in global governance until the opening of the UN's main seat in New York after the Second World War.

${ }^{23}$ Hilary Charlesworth and Christine Chinkin have documented 'the absence of women at senior levels in international institutions'; see H. Charlesworth and C. Chinkin, The Boundaries of International Law: A Feminist Analysis (2000), at 171.

${ }^{24}$ As Bernard Cohn once described it, ' $[\mathrm{t}]$ he past exists not only in records of the past, but survives in buildings, objects and [social and built] landscapes of the present day'. B. S. Cohn, 'History and Anthropology: The State of Play', (1980) 22(2) Comparative Studies in Society and History 198, at 221.

${ }^{25}$ See H. Lefebvre, The Production of Space (1991), 227. See also M. Foucault, 'Des Espace Autres', (1984) 5 Architecture, Mouvement, Continuité, 5, 46-9; D. Massey, For Space (2005).

${ }^{26}$ See J. Ranciere, The Politics of Aesthetics (translated by G. Rockhill) (2004), 51. See also J. Rancière, Aesthetics and its Discontent (2009).

${ }^{27}$ N. Kretzer, 'Information Materials': Smart Materials for Adaptive Architecture (2017), at 26.

${ }^{28}$ See C. Douzinas, and L. Nead (eds.), Law and the Image: The Authority of Art and the Aesthetics of Law (1999); D. Evans, 'Theatre of Deferral: The Image of the Law and the Architecture of the Inns of Court', (1999) 10(1) Law and Critique 1; L. Nead, 'Visual Culture of the Courtroom: Reflections on History, Law and the Image', (2002) 3 Visual Culture in Britain 119.
} 
figures of courtroom design, and the artistic motifs and iconographical emblems which fill them the 'scales of Justice' or the personification of the Virtue Justice, coats of arms, flags, state emblems - speak to the legal narratives which law seeks to impart upon its participants. 'Law needs to stand out from the mundanity of other institutions', writes Piyel Haldar 'the elegance of legal architecture provides the background against which justice is seen to be done; it advertises itself as a select and exclusive space in which a monopoly over the administration of justice according to rational precepts is supposed to reign. ${ }^{29}$ In modern settings, the visual power of law is most commonly seen in the image of the courthouse, 'the new fulcrum around which the mechanism of selfrepresentation in the various modern states' pivots. ${ }^{30}$ There, as Judith Resnik has argued, attitudes about the law, the roles of judges, litigants, lawyers, and the public audience dominate the organization of space. ${ }^{31}$ Architecture and imagery, she asserts, serve as a necessary precondition for the work of law, instilling legal practices with ideas of style, identity, inclusivity and exclusion, and delineating the ordered world of law and its projection of a sense of internal coherence. Similarly, Linda Mulachy in her genealogy of legal architecture develops a fascinating narrative of the role physical manifestations of law, justice and power have played in creating legal identities in England and Wales. ${ }^{32}$

As a growing body of research has shown, international law is equally dependent upon aesthetics and spatial dynamics to elicit faith in its ideals and principles, and to project international legal discourse to the outside. ${ }^{33}$ As international law was brought into focus during the late nineteenth century, with the establishment of international organizations and institutions, moves to create a visual language of expression for internationalism and efforts of international law became a central concern. Having operated as a key spatial strategy in the context of both European nation-building ${ }^{34}$ and imperial expansion during the eighteenth and nineteenth centuries, ${ }^{35}$ architectural expression was to assume a central role in lending a newly imagined presence to the international legal community through the design of its organizational and administrative spaces. Unlike earlier international organizations, which were housed in existing buildings, the decision to commission specially-made structures was both a practical necessity and a conscious political decision evoking the permanency of the endeavour. The desire for international institutions to reside in structures that reflected both the institutional and architectural ambitions of their founders was clear from the architectural briefs that articulated very clearly what the design and function of these buildings should embody. ${ }^{36}$ These were the first buildings of their kind and are thus

\footnotetext{
${ }^{29} \mathrm{P}$. Haldar, 'The Function of the Ornament in Quintillian, Alberti and Court Architecture', in C. Douzinas and L. Nead (eds.), Law and the Image: The Authority of Art and the Aesthetics of Law (1999), 135; L. Dahlberg, 'Introduction. Visualising Law and Authority', in L. Dahlberg (ed.), Visualising Law and Authority: Essays on Legal Aesthetics (2012), 1.

${ }^{30}$ G. Muratore, 'Law courts in the modern city', (1988) 14 Zodiac at 45.

${ }^{31}$ J. Resnik and D. E. Curtis, Representing Justice: Invention, Controversy, and Rights in City-States and Democratic Courtrooms (2011).

${ }^{32}$ L. Mulcahy, 'Architects of justice: The politics of courthouse design', (2007) 16 Social and Legal Studies 383.

${ }^{33}$ See, e.g., R. Niezen and M. Sapignoli (eds.), Palaces of Hope: The Anthropology of Global Organizations (2017); J. Hohmann and D. Joyce (eds.), International Law's Objects: Emergence, Encounter and Erasure through Object and Image (2018); L. Boer and S. Stolk (eds.), Backstage Practices of Transnational Law (2019).

${ }^{34}$ See B. Anderson, Imagined Communities: Reflections on the Origins and Spread of Nationalism (2006); A. Smith, Myths and Memories of the Nation (1999).

${ }^{35}$ As Fassil Demissie argues, 'more than steamboats, machine guns, cameras and other material objects of colonialism, architecture and urbanism made the empire visible and tangible'. F. Demissie (ed.), Colonial Architecture and Urbanism in Africa: Intertwined and Contested Histories (2012). See also E. Said, Culture and Imperialism (1993), 226. Ruth Craggs and Claire Wintle have recently underscored the profound need to re-politicize architecture and urbanism and its implications for the enactment of decolonization; see R. Craggs and C. Wintle, Cultures of Decolonisation: Transnational Production and Practices 1945-70 (2017).

${ }^{36}$ J. P. Chupin, C. Cucuzzella and B. Helal, Architecture Competitions and the Production of Culture, Quality and Knowledge (2015).
} 
symbolically charged buildings, uniquely defined by international politics, and a complex set of functional requirements. The conceptualization of place, the inherent spatial analogies and iconography implied in these new international legal structures, reveal the international normative and institutional discourses which sought to constitute a particular kind of order and international legal authority. ${ }^{37}$ The design of these spaces was not only an abstract expression of an international legal culture - they also impacted the operation of international law. How these structures were to be organized - where the international actors were positioned, how assembly and meetings rooms were arranged, right down to the number of seats included in assembly spaces and plenary halls, was to have an enormous impact on the function of international legal co-operation, and would characterize the different visions and polities of international law across different eras.

However, as Mark Crinson has recently explored in his enlightening account of modern architecture and internationalism, it was unclear, in aesthetic terms, how internationalism would be evoked beyond the specifics of culture and history. ${ }^{38}$ While a relatively clear idea of national identity had developed over the proceeding century, the idea of a political community spanning nations (imagined, geographic, and conceptual) posed a new challenge. Moreover, the question arose as to how aspirations of international law and its institutions were to be conveyed. Was the establishment of international organizations a matter of law or politics, of diplomacy or ethics or all of these? Did internationalism merely imply relations between nations, or did it invoke a new kind of identity akin to the nation's search for a political community? And if it was to be separated from the politics of the nation what sort of visual language could be said to represent a borderless free space of the 'international'? ${ }^{39}$

The tension between those who saw international law as a 'law of nations' embodied in the early modern approach exemplified by the writings of Grotius, and those who sought a new rhetoric that surpassed the nation was to reflect what Martti Koskenniemi calls the "pervasive opposition between more or less "idealistic" and "realistic" approaches that still structure professional imagination in the field'. ${ }^{40}$ Discussions over the dynamic between sovereignty and individualism, the state and the supra-national community, the influence of technology and economic growth on the state, which would come to dominate broader debates over the development of the field of international law, would be equally reflected in aesthetic deliberations concerning representations of international law. Early attempts at designing international structures were met with a mostly conservative attitude regarding the role of international law as a facilitator of 'the fraternal approach of the nations' ${ }^{41}$ rather than as a new supranational entity of world governance.

Evidence of this debate can be seen in the design of the Peace Palace in the Hague, built in 1905 to house the Permanent Court of Arbitration (Figure 1 below). ${ }^{42}$ The project was funded by the Carnegie Foundation together with the Dutch government, who held an international design competition to decide the design of the 'stately and of [sic] noble' home of the court, ultimately selecting a design by the French architect Louis Cordonnier. ${ }^{43}$ Evoking the neo-renaissance aesthetic of the Amsterdam Town Hall of 1652, the jury praised Cordonnier's design for 'following the local

\footnotetext{
${ }^{37}$ See, e.g., D. Litwin, 'Stained Glass Windows, the Great Hall of Justice of the Peace Palace', in J. Hohmann and D. Joyce, International Law's Objects (2018), 463.

${ }^{38}$ Crinson, supra note 3 , at 5 .

${ }^{39}$ Eighty years later when Richard Rogers designed the European Court of Human Rights building, he described the challenges involved in moving beyond one national style: R. Rogers, 'European Court of Human Rights', (1995) 14 Zodiac 196.

${ }^{40} \mathrm{M}$. Koskenniemi, 'The Legacy of the Nineteenth Century', in D. Armstrong (ed.), Routledge Handbook of International Law (2009), 141, at 142.

${ }^{41}$ 'Discours du Président du Comité des Directeurs de la Fondation Carnegie, Jonkheer A. Van Karnebeek à l'occasion de l'ouverture du Palais de la Paix, 28 Août 1913', available in the archive of the Carnegie Foundation, Peace Palace, The Hague.

${ }^{42}$ Crinson, supra note 3 , at 22.

${ }^{43} \mathrm{~J}$. Resnik and D. Curtis, Representing Justice: Invention, Controversy and Rights in City-States and Democratic Courtrooms (2011), at 251 .
} 


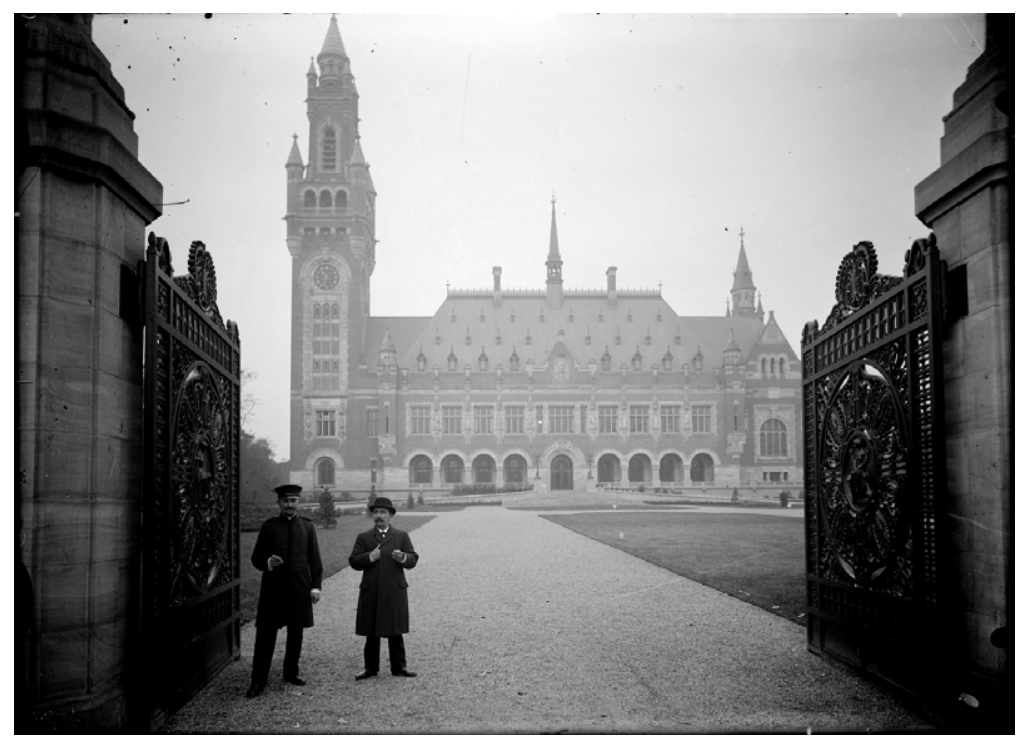

Figure 1. Peace Palace, The Hague, 1913 Photo: The Hague (c) The Brand The Hague.

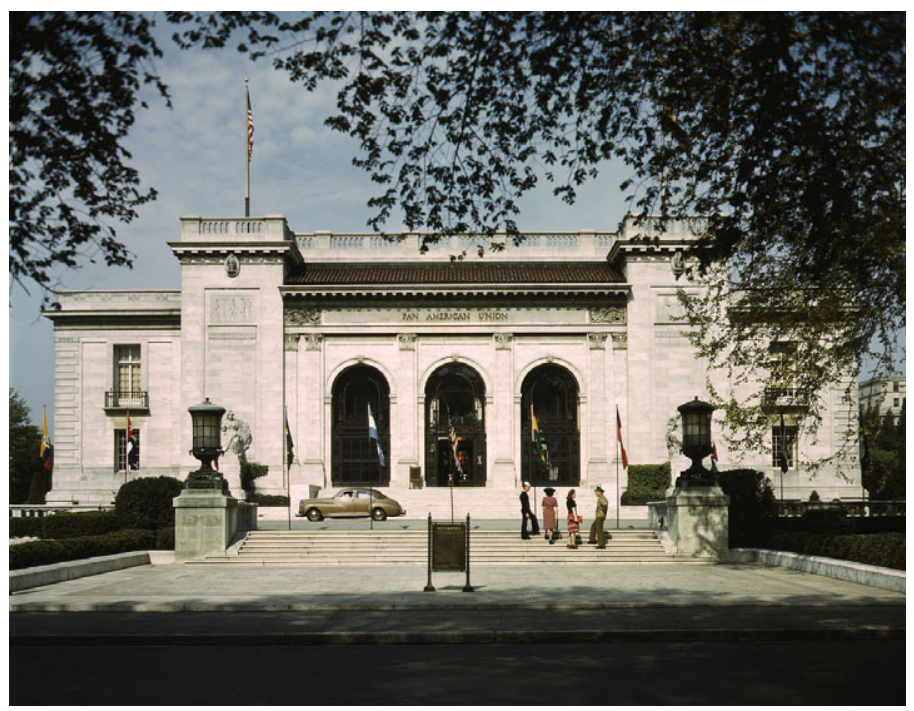

Figure 2. "Front view of the Pan American Union, Washington, D.C." May 1943, Photo: John Collier, courtesy of the United States Library of Congress Prints and Photographs Division.

traditions of XCI Century architecture' in the Hague, while architect Arthur Eyffinger described the structure as loyal to 'the pillars of the Dutch Golden Age: Christian faith, the wealth of the merchant class and classical learning. ${ }^{44}$ Expressions of internationalism were clearly anchored in

${ }^{44}$ A. C. G. M. Eyffinger, The Peace Palace: Residence for Justice, Domicile of Learning (1988). 
a national (Dutch) aesthetic, in a visibly grand and historicist style, reflecting the preferences of a selective elite composed of mainly Western diplomats and academics (much like the supposedly universal ideals the Palace was said to embody). ${ }^{45}$ This can also be seen in the visualizations of the story of universal justice in the Palace's decorations and gifts, which were 'littered with symbols of Christian and humanist virtue'. ${ }^{46}$ Critics, however, decried it as a parochial and backward looking, criticizing its 'lack of world harmony' and calling the design 'wholly imitative of the architecture of another era, without the slightest effort at large symbolism of modern life'. ${ }^{47}$ If we compare the final design to the Pan American Union Headquarters (Figure 2 above), also commissioned by the Carnegie Foundation and built two years later in 1908, it was a very different form of expression that was to represent the newly established Pan American Union. Rather than elevating one single nation style, the structure blended North and South American expression by combining contemporary Beaux-Arts expression with elements alluding to the Spanish colonial architecture of the Latin America member states, such as the terracotta roof, ornamental bronze work, Aztec and Mayan artwork, and tiled central courtyard that featured flora from across the Americas. ${ }^{48}$ The harmonious combination of these various national design elements, and its more contemporary and unique aesthetic, could not be more estranged from the dated visual expression of the Peace Palace.

\section{Benign internationalism: The first International Geneva Building 1922-26}

Ideas of internationalism were to undergo a radical transformation in the aftermath of the First World War. The Versailles Settlement and the creation of the League of Nations was viewed as 'the inauguration of an era of bold legal experimentation'. ${ }^{49}$ A new spirit of internationalism emerged, intending to displace old world diplomacy with technical mastery and transparent co-operation between states. ${ }^{50}$ These shifts in supranational activity are largely depicted as coalescing into the broader rise of modernism in other cultural domains. Nathaniel Berman, for example, argues that like other 'cultural modernists - whether artists, literary writers, psychoanalysis or political theorists' - the new endeavours international lawyers participated in created deep shifts in cultural history. ${ }^{51}$ Just as cultural modernists efforts were directed at transcending what they saw as the artifice of nineteenth century bourgeois culture, Berman's wider thesis is that a 'new international law' created by these 'modernist' jurists and officials was based on a paradoxical 'alliance' of the 'experimental' and the 'primitive' against the construct that formerly constituted international law's foundation: the state. ${ }^{52}$

Architecture was to emerge as a litmus test for modernism, seen in the shift towards modernism architectural expression which swiftly emerged. ${ }^{53}$ Anchored in efforts to counteract the divi-

\footnotetext{
${ }^{45}$ See M. Duranti, The Conservative Human Rights Revolution. European Identity, Transnational Politics, and the Origins of the European Convention (2017), at 31.

${ }^{46}$ Ibid., at 39.

${ }^{47}$ Resnik and Curtis, supra note 43 , at 251.

${ }^{48} \mathrm{P}$. Scott and A. Lee, Buildings of the District of Columbia (1993), at 209-10.

${ }^{49}$ N. Berman, 'Modernism, Nationalism, and the Rhetoric of Reconstruction', (1992) 4 Yale Journal of Law and the Humanities 351, at 366.

${ }^{50}$ Kennedy, supra note 12; W. G. Grewe, The Epochs of International Law (translated by M. Byers) (2000), at 575.

${ }^{51}$ Berman, supra note 49 , at 353-4.

${ }^{52}$ Ibid., at 354, 366. This 'asymmetrical alliance', in Berman's terms, involved the 'juxtaposition of the new status for nations and a new autonomy for the international community' in the form of the League of Nations. Its aim was to allow international law to bypass the state by means of a 'double' movement of re-authorization 'up' to the level of the international and 'down' to that of the national.

${ }^{53}$ Crinson, supra note 3, at 93. For a discussion of early modern examples see A. Payne, From Ornament to Object: Genealogies of Architectural Modernism (2012); J. L. Cohen, The Future of Architecture Since 1889: A Worldwide History (2012); W. Curtis, Modern Architecture Since 1900 (1982).
} 
sive effects of unbridled nationalism and archaic historicism, modernists sought to create 'a unifying aesthetic language'. 54 'Cooperation rules the world', stated Hannes Meyer, 'it is cosmopolitan and the expression of an international philosophy is building'. ${ }^{55}$ Rather than 'individual despotism' which it associated with the pre-war world, 'universally comprehensible expression ... which organises the progress of humanity' was the new mantra, centred upon a neutral, functional style. ${ }^{56}$ The transparency and spatial openness evoked by Walter Benjamin's glass and steel architecture, would encapsulate the transparency and utopian ideals of a new socio-cultural ideal. ${ }^{57}$ In Benjamin's view, the architecture of modernism was a movement of awakening closely linked to his call for a new start for humanity. ${ }^{58}$

This utopian impulse to free itself from history and the symbols of the previous century was, however, to be rendered conspicuously absent in the design of the First International Geneva building, commissioned in 1923 for the ILO. As the first structure designed for the newly formed League of Nations, its construction raised the question of how to frame post-war international subjectivity, along with the critical issue of what it was to be an international organization in the post-war climate. ${ }^{59}$ Seen in this context, the choice to eschew emergent streams of modernism in favour of Swiss architect George Epitaux's nineteenth century romantic design expresses a cautious and technocratic vision of the new international institutional order (Figure 3 below) ${ }^{60}$ Completed in 1926, a year before the Lotus case - where for the first time international law confronted the question of whether the international legal order was fundamentally one of sovereign freedom or constraint, ${ }^{61}$ the building speaks to a reluctant sovereign compromise between nationalism and internationalism, and a desire to ground the technical and benign character of international organizations in a pre-modern functionalism. In many ways, therefore, the building's conservatism sits oddly with the dominant history of the early interwar period and its projected sense of a renewed international community based upon law and institutional co-operation.

Despite the atmosphere of co-operation emanating from the immediate post-war environment, a deep ambivalence remained surrounding the compatibility of state sovereignty with membership in international organizations. ${ }^{62}$ Internationalists countered by stressing that the technical character' of international co-operation would strengthen and not endanger national sovereignty, by providing a pragmatic approach to common problems. ${ }^{63}$ The politics of technocracy was clearly visible in the establishment of the ILO in 1919, an institution which would facilitate a world trading system for the benefit of all states. ${ }^{64}$ This was to be based on peaceful compromises and treaties, with the ILO working to elaborate international conventions with the intention of providing

\footnotetext{
${ }^{54}$ Crinson, Ibid., at 12.

${ }^{55}$ H. Meyer, 'Die Neue Welt', (1926) 13 Das Welt 7, translated in Hannes Meyer - Bautenm Projekte und Schriften (1965).

${ }^{56}$ De Stijl, 'Manifesto 1', originally published in De Stijl, V, no. 4, 1922, translated and published in C. Harrison and P. Wood, Art in Theory 1900-2000 (2003), at 281.

${ }^{57}$ D. Mertins, 'The Enticing and Threatening Face of Prehistory: Walter Benjamin and the Utopia of Glass', in B. Hanssen (ed.), Walter Benjamin and the Arcades Project (2006), at 229.

${ }^{58} \mathrm{~W}$. Benjamin, The Arcades Project (translated by H. Eiland and K. McLaughlin, prepared on the basis of the German volume edited by R. Tiedemann) (1999), at 462.

${ }^{59}$ Crinson, supra note 3 , at 97.

${ }^{60}$ For a discussion of the role of architectural competitions in designing international buildings see J. P. Chupin, C. Cucuzzella and B. Helal, Architecture Competitions and the Production of Culture (2015).

${ }^{61}$ The Permanent Court famously concluding that 'restrictions upon the independence of States cannot ... be presumed', S.S. Lotus (France v. Turkey), 7 September 1927, PCIJ Rep Series A no 10.

${ }^{62}$ A. Peters and S. Peter, 'Between Technocracy and Democracy', in B. Fassbender and A. Peters (eds.), The Oxford Handbook of the History of International Law (2012), 171, at 193.

${ }^{63}$ Ibid., 194. See also A. H. Fried, Das internationale Leben der Gegenwart (1908), at 31-3; P. Clavin and J. W. Wessel, 'Transnationalism and the League of Nations: Understanding the Work of its Economic and Financial Organisation', (2005) 14 Contemporary European History 465, at 491.

${ }^{64}$ A. Thomas, 'The International Labour Organization: Its Origins, Development and Future', (1921) 1 International Labour Review 5.
} 


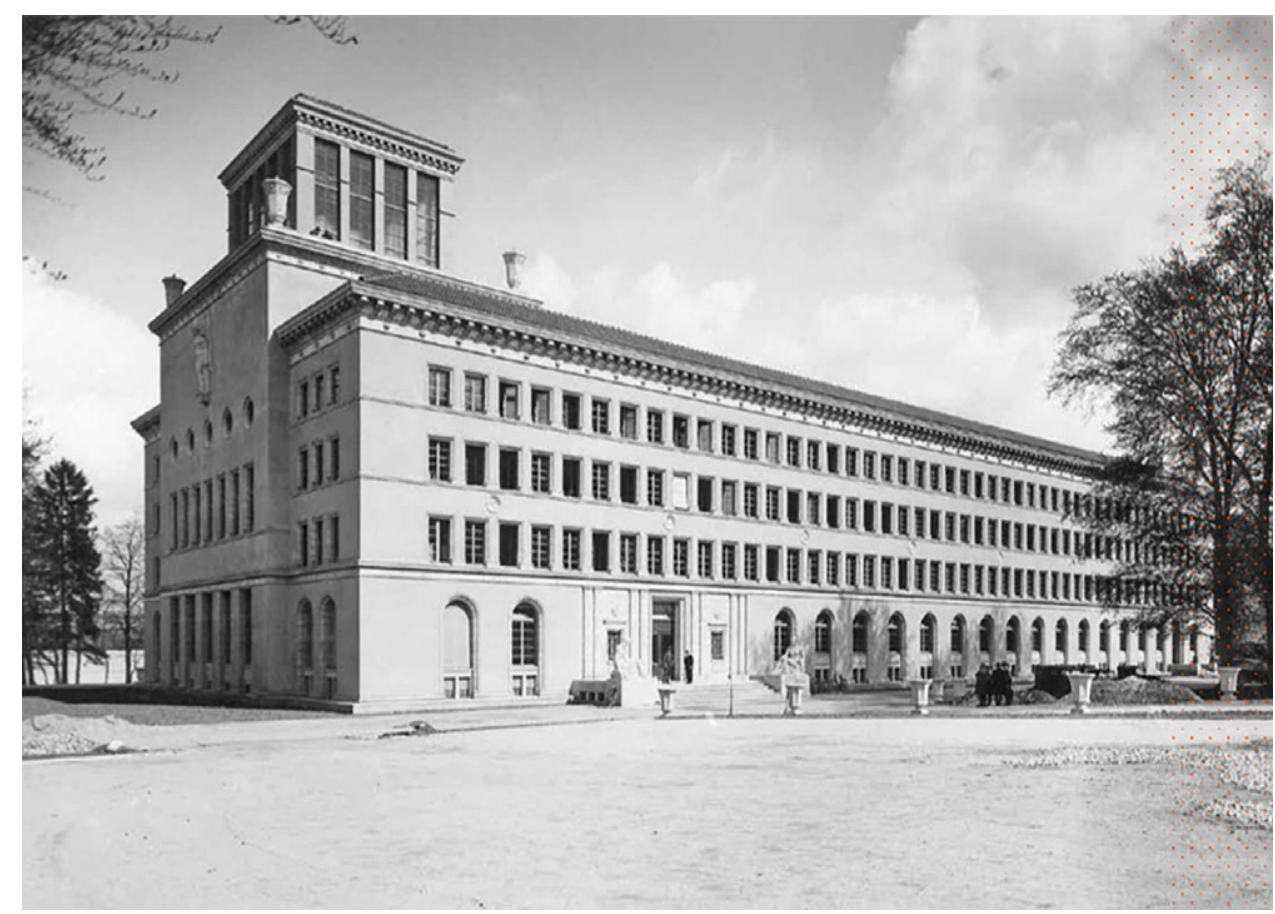

Figure 3. First International Geneva building, built in 1926, by Georges Epitaux, for the International Labour Organization, Photo: ILO (c) ILO Historical Archives.

universal rules and regulations, as well as technical assistance to members. ${ }^{65}$ The decision to focus international attention on issues of labour was driven not only by the growing integration of the world economy but by the growing levels of exploitation and labour unrest which was widespread during the period. This was in many ways a revolutionary undertaking. However, there was also an increasing awareness not only of the 'threat of radical worker mobilization', but of a highly competitive and interdependent international economic community which necessitated parity in working conditions. ${ }^{66}$ The ILO would therefore promote a more 'equitable' form of capitalism in which worker rights and social justice would feature to prevent more revolutionary change. ${ }^{67}$

Understood in this physical and historical context, the building where the ILO was to be housed sought to stress this benign and technical character. In this respect, the significance of the League's decision to construct the Palace of Labour before the Palace of Nations, should not be overlooked. The competition brief asked architects to produce a building expressing 'the dignity fitting to an international institution ...' ${ }^{68}$ Despite a host of creative and original design submissions, the jury selected a sombre, quadratic structure by George Epitaux, modelled on a Florentine villa but more evocative of a concrete office block. Built amidst a lush, lakeside plot, the building's relationship to the surrounding greenery emotes an isolationist tension, while its uniform, grid-like facades comprising close-set narrow windows create an imposing exterior of identical bureaucratic cells.

\footnotetext{
${ }^{65}$ S. Kott, 'From Transnational Reformist Network to International Organization: The International Association for Labour Legislation and the International Labour Office (1900-1930s)', in D. Rodogno, B. Struck and J. Vogel (eds.), Shaping the Transnational Sphere. Experts, Networks, and Issues (c. 1850-1930) (2015), 239.

${ }^{66} \mathrm{Ibid}$.

${ }^{67}$ B. Langille, 'Labor', in J. Cogan, I. Hurd and I. Johnstone (eds.), The Oxford Handbook of International Organisations (2016), 473.

${ }^{68}$ J. Kuntz, 'Chapter 3: The William Rappard Centre: From a Tree's Perspective', in International Geneva. 100 years of Architecture (2016), available at www.geneve-int.ch/node/4153.
} 
Indeed, standing in the central courtyard, one gets the sense of standing amidst a great panopticon. While some decorative features can be found, including some neo-classical ornate cornices and artificial stone surrounding the windows, it is largely devoid of surface decoration. The building's visual focus is the large cupola adorning one end which breaks up the otherwise symmetrical and monolithic exterior. The building speaks overwhelmingly of discreet, unassuming and unemotive bureaucracy - indeed Epitaux rejected the description 'palace of labour', preferring usine intellectuelle (factory for intellectuals). ${ }^{69}$ In keeping with the building's inconspicuous style, Epitaux adopted the pre-modernist national dialectic of neo-classicism which was the preferred national style in Switzerland ${ }^{70}$ and in stark contrast to the Futurist style, which drew inspiration from the industrial and mechanical man-made world, that had come to personify the Soviet workers' movement.

With the threat of Bolshevism looming, the conspicuous iconography contained within the ILO building is one of its most symbolic aspects. The neo-classicism of the exterior continues inside with its grand, stone and wood panelled interiors. The ILO's precarious mission - the protection of workers' rights within a reformed capitalist framework - finds expression in the exhibited artworks. Attempts to distinguish the ILO's political vision of labour as something different from the revolutionary socialist labour movement, can be seen in the various depictions of labour expressed in biblical terms. ${ }^{71}$ Indeed, Epitaux even described the ILO building as 'a temple in which work was God'. ${ }^{72}$ Amongst these is a large mural entitled 'The Dignity of Labour', commissioned by the International Federation of Christian Trade Unions, which depicts Jesus Christ in a workshop in Nazareth talking to a group of labourers in modern dress. References to the Christian work ethic can also be seen in Jorge Colaco's murals 'Fishing', 'Grape Picking', and 'Agriculture' which depict exaggerated and saintly characterizations of workers. Additionally, the building was decorated with the objects donated by states (almost all European); ${ }^{73}$ a conciliatory gesture that no doubt sought to temper the outwardly nationalist expression of the building's exterior. ${ }^{74}$

Ultimately, as Joelle Kuntz explains, the building's attempt to fuse the technical character of the ILO with a classical, 'unpretentious' style was widely criticized for its lack of aesthetic and political vision. ${ }^{75}$ Yet, as the building's pragmatic conservatism illustrates, it was already clear that international organizations were caught in an impossible bind - between elevating internationalism and placating state sovereignty. This dynamic mirrored the role of the ILO during its initial years. While in the first few years of its operation, the ILO had adopted nine International Labour Conventions and ten Recommendations, which dealt with hours of work, unemployment, maternity protection, night work, and the minimum age, by 1926 when the building was inaugurated, this initial zeal had been toned down for political reasons. Governments felt there were too many Conventions, the budget too high and the reports too critical. ${ }^{76}$ The great irony was that the 'technicality'- topos which was to be fervently expressed in the ILO building, was debased by critics who felt that the League should concentrate on its political mission to foster international peace and security. ${ }^{77}$

\footnotetext{
${ }^{69}$ Ibid.

${ }^{70}$ Kuntz, supra note 68.

${ }^{71}$ Crinson, supra note 3 , at 97.

${ }^{72}$ Ibid.

${ }^{73}$ ILOA G/502/2.

${ }^{74}$ Crinson, supra note 3 , at 96.

${ }^{75} \mathrm{Kuntz}$, supra note 68.

${ }^{76}$ See F. Schipper, Driving Europe: Building Europe on Roads in the Twentieth Century, PhD thesis Eindhoven University of Technology (2008), Ch. 3.

${ }^{77}$ See S. Pedersen, 'Back to the League of Nations', (2007) 112 American Historical Review 1091, at 1108, referring to Secretary-General Drummond who complained about the intensifying activities of the League in allegedly non-political affairs.
} 


\section{Temple on the lake: The League of Nations Headquarters, Geneva 1927-1937}

The disjuncture between broader modernist aesthetic and political expressions of international law and order was to become even more prominent during the construction of the Palace of Nations beginning in 1927. By this time modernism had achieved an even broader appeal, based upon the vision of a borderless community. This necessitated an architectural language that could be communicated across cultural divides, a 'figurative Esperanto', in Otto Neurath's terminology ${ }^{78}$ But the belief in a language more logical and comprehensible because of its rootedness in an 'essence' of humanity appealed, in Theodore Adorno's optic to a 'false comprehensibility'. ${ }^{79}$ Esperanto's constructed neutrality, was in reality an amalgam of European languages, and attempts to make it the working language of the League were ultimately blocked by the French government, who were concerned about French losing its position as 'the international language'. ${ }^{80}$ The search for an appropriate architectural expression for the new model of peaceful international cooperation embodied by the League was to be equally as fraught.

In contrast to the ILO, the League was, from the onset, perceived to be the first 'political' organization, with its mandate 'to promote international cooperation and to achieve international peace and security'. The construction of the League Headquarters, therefore, was from the outset a symbolically charged endeavour. Known in architectural circles as the ultimate showdown between academicism and modernist architecture, the international competition held to determine the design is in itself one of the most illuminating and controversial episodes of interwar diplomatic dysfunctionality. ${ }^{81}$ The competition drew over 377 entries, including those of modernists Le Courbusier and Hannes Meyer, whose designs sought to anchor the League's political vision in modernist internationalism. Their designs were, however, starkly at odds with those of the European political elite overseeing the project. ${ }^{82}$ As it became increasingly evident that the League was in no hurry to displace existing political hierarchies, architecture of a classic European style came to represent the new international order which ultimately preserved the imperialist structures of the Great Powers. The chosen design - a neo-classical structure that required enormous expense and took almost a decade to build ${ }^{83}$ - was to quite literally set the paradoxical and defective aspects of the League in stone at the Palace of Nations (Figure 4 below).

For inter-war jurists, the League was founded on a vision of modernization; one in which the defective framework of old-European diplomacy would be substituted with a new international law better able to grapple with the era's legal and political challenges. One of the overwhelming challenges confronting the post-war era was the question of how to address the shifting perimeters of nation states borne by the collapse of the Habsburg, Hohenzollern, Ottoman, and Romanov empires. ${ }^{84}$ Against this backdrop, a paradoxical alliance was formed between nationalism and 'a newly autonomous international law' embodied in Woodrow Wilson's calls for the selfdetermination of peoples. ${ }^{85}$ International peace, it was argued, required a more democratic international structure allowing no nation to dominate another, but that all people should be left to determine their own form of government, their own path of development, 'unhindered,

\footnotetext{
${ }^{78}$ O. Neurath, Athens Lecture, quoted in Crinson, supra note 3, at 85.

${ }^{79}$ T. Adorno, Minima Moralia - Reflections from Damaged Life (translated by E. F. N. Jephcott) (2005), 150.

${ }^{80} \mathrm{~J}$. Mowbray, 'Towards a More Radical Deterritorialisation of Language', Voelkerrechtsblog, 28 November 2016, available at voelkerrechtsblog.org/towards-a-more-radical-deterritorialiation-of-language/.

${ }^{81}$ J. P. Chupin, C. Cucuzzella and B. Helal, Architecture Competitions and the Production of Culture, Quality and Knowledge (2015).

${ }^{82}$ S. Giedion, Space, Time, and Architecture (1938), 441.

${ }^{83}$ In 1935 , the final invoice was presented to the $16^{\text {th }}$ Assembly of the League of Nations: 29.5 million francs, not counting the library, built thanks to an outside donation of 2.2 million francs, accepted by vote in 1927, which rose to 5.5 million by the end of construction.

${ }^{84} \mathrm{~N}$. Wheatley, 'Spectral Legal Personality in Interwar International Law: On New Ways of Not Being a State', (2017) 35 Law \& History Review 753, at 762.

${ }^{85}$ Berman, supra note 49 , at 365 .
} 
unthreatened, unafraid, the little along with the great and powerful. . ${ }^{86}$ Unsurprisingly, the long list of exceptions to this rule of the governed emerged almost immediately. Self-determination did not apply, wrote Robert Lansing, Wilson's foreign secretary, to 'races, peoples, or communities whose state of barbarism or ignorance deprive them of the capacity to choose intelligently their political affiliations' ${ }^{87}$ Independence movements of people under colonial control, or of stateless or marginalized peoples and minorities were mostly ignored, in favour of preserving the imperialist and hegemonic power of the victors. Instead, a system of minorities, treaties, and international tutelage was to oversee the administration of territories under colonial control, on the understanding that (as Article 22 of the Covenant put it) 'the well-being and development of [those territories'] peoples form a sacred trust of civilization'. ${ }^{88}$ Taken together, this situation underlined the seemingly conflicting nature of the League's responsibilities. As Susan Pedersen notes, on the one hand, the League was to promote emerging norms related to trusteeship and human rights; on the other hand, it was to do so without undermining the principle of state sovereignty. ${ }^{89}$

The architectural competition held to determine the design of the Palace spoke volumes about the contradictory internationalist ethics of the League. While in 1924, the committee appointed by the Assembly of the League of Nations to manage the competition opted to make it 'universal', an outcry from states led to it limiting the competition to architects from the League of Nations' 55 member states. ${ }^{90}$ The jury, moreover, was to be comprised of architects 'of countries geographically close to the seat of the League', ${ }^{91}$ resulting in an entirely European-based jury. The brief called for a design combining all the essential organs necessary for the operation of the League, conveyed 'in a practical and modern fashion' and symbolizing 'the pacific ideals of the twentieth century through the purity of its style and the harmony of its lines' ${ }^{92}$ Despite hundreds of diverse proposals being received invoking every possible national, academic, and modernist style, the jury refused to appoint a winner declaring that none of the projects had fulfilled the conditions of the competition. Ironically, given the nature of the task, the chairman blamed the differing cultural and aesthetic sensibilities of its members which prevented them from reaching a consensus. ${ }^{93}$ Ultimately, the commission was granted to a group of conservative Academy architects from France, Hungary, and Italy, appointed by the jury. The decision was met with an outcry, particularly when it was revealed that Le Corbusier's project was the only design to have fulfilled all the desired criteria, including the all-important budgetary requirement. To rub more salt in the wound, it later emerged that Le Corbusier had been disqualified for a minor infraction: rather than hand-drawing his designs as the competition had demanded, he had had them machine printed.

Many recognized, however, that the real problem was that Le Corbusier's proposed building was simply too starkly different from the preferred expressions of European political power. Le Corbusier had entirely refuted traditional ceremonial classicism, devising a modernist design which he felt would provide a more neutral, universal backdrop for international diplomacy and community-building. ${ }^{94}$ As he later stated: 'This palace was for working and listening. We made a large office building and invented a new architectural form: a room for listening. ${ }^{95}$ In

\footnotetext{
${ }^{86} \mathrm{~W}$. Wilson, quoted in E. Manela, The Wilsonian Moment: Self-Determination and the International Origins of Anticolonial Nationalism (2007), at 24.

${ }^{87} \mathrm{R}$. Lansing, quoted in ibid.

${ }^{88}$ On the mandates system and its effect on the colonial order see S. Pedersen, The Guardians: The League of Nations and the Crisis of Empire (2015).

${ }^{89}$ S. Pedersen, 'Back to the League of Nations', (2007) 112 American Historical Review 1091, at 1092.

${ }^{90} \mathrm{Kuntz}$, supra note 68 , at Ch. 5 .

${ }^{91}$ (1924) League of Nations Official Journal, 5/1369.

${ }^{92}$ Competition Program, quoted in Crinson, supra note 3, at 116.

${ }^{93}$ Quoted in ibid., at 119 .

${ }^{94}$ Le Corbusier, 'L'Esprit Nouveau', unpublished text of 1920, quoted in M. Christine Boyer, Le Corbusier, Hommes de Lettres (2011), at 280.

${ }^{95}$ Letter from Le Corbusier to Karl Moser, Paris, 30 January 1927, quoted in Kuntz, supra note 68, at Ch. 5.
} 
keeping with the building's futurist style, it incorporated new technical solutions to maximize light and improve acoustics for diplomatic discussion, while the building's harmonious integration into the surrounding landscape and synthesis of structural and material elements to create a sense of openness and public accessibility. ${ }^{96}$ Hannes Meyer's vision of internationalism was equally as distinctive. Devoid of symbolic motifs or spaces, the proposed buildings avoided any sense of ceremony, and were almost industrial in their feel. In the text accompanying his submission, Meyer wrote, the League would promote 'public debate' in an 'open assembly', it would 'fight against practices of an outworn nationalism and ... strive to give the comity of nations a new form': ${ }^{97}$

if the intentions of the League of Nations [to represent the pacific glory of the XX century] are sincere, then it is not possible to constrain such an innovative social organization to the straitjacket of traditional architecture. No colonnaded hall for bored sovereigns, but salubrious working rooms for the busy representatives of the various peoples. No dark corridors for the intrigues of diplomacy, but open, glazed spaces for public negotiations carried by honest men. ${ }^{98}$

What the League of Nations actually built was an entirely different affair. Le Corbusier and Meyer's visions of a twentieth century internationalism, infused with modernist and technological flair, were in stark contrast to the conventional neo-classical 'palace' that was constructed. Constructed out of polished sandstone and travertine, the building's rectilinear five-story facades are framed by unadorned columns and pilasters and capped with an imposing moulded roof. Like a classic Greek temple the axial structure is divided into two horseshoe shaped wings housing the Assembly and secretariat, connected by a narrow walkway, and flanked by a grand stone staircase leading from the Assembly Hall to the central court, which represents the visual focus of the building. The awkward, sloping plot of land and the need to provide ample office space, combined with the architects' desire to retain a classic monumental design, meant that the building adopts strange, overextended proportions overall. This conventional monumental scheme proved to be one of the main stumbling blocks of the final design, as problems of access between the two buildings ensued. Poor ventilation and lack of light, particularly in the hermetically sealed secretariat building and inwardly looking office spaces, proved immediately problematic. The building manifests a tension between the outward grandiosity of public diplomacy, and a closed, inaccessible bureaucracy, seen, for example, in the difference between the open court of the main assembly building, and the closed court of the secretariat. The contrast between the dark, cramped office interiors of the secretariat and the lofty, marble clad corridors and meeting rooms of the assembly building further highlight this tension. Inside a series of allegorical works mirroring the building's classicism were featured in prominent locations, including Eric Gill's The Creation of Adam, The Power of Peace by Maurice Denis, and three large murals by Jose Maria Sert on the theme of The Solidarity of Peoples, as well as the prominent placement of two winged genii by Hubert Yencesse inside the Assembly Room. ${ }^{99}$ Overall, however, the interiors mark a stark contrast from the external design. The art deco furnishings, woodwork and wall decorations embody a more minimalist, functional aesthetic, which suggests that by the time it came to decorate the interiors in the late 1930s, modernism's grip on the inter-war aesthetic was virtually unavoidable. ${ }^{100}$

\footnotetext{
${ }^{96}$ For a discussion of Le Corbusier's design see K. Frampton, Le Corbusier (2001), 81-5; M. Christine Boyer, supra note 94, at 400-6; T. Benton, 'The Era of Great Projects', in M. Raeburn and V. Wilson (eds.), Le Corbusier - Architect of the Century (1987), at 166 .

${ }^{97}$ Quoted in Frampton, ibid., at 83.

${ }^{98}$ Ibid.

${ }^{99}$ C. Pearson, Designing UNESCO: Art, Architecture and International Politics at Mid-Century (2010), at 71.

${ }^{100}$ See Kuntz, supra note 68, at Ch. 5 .
} 


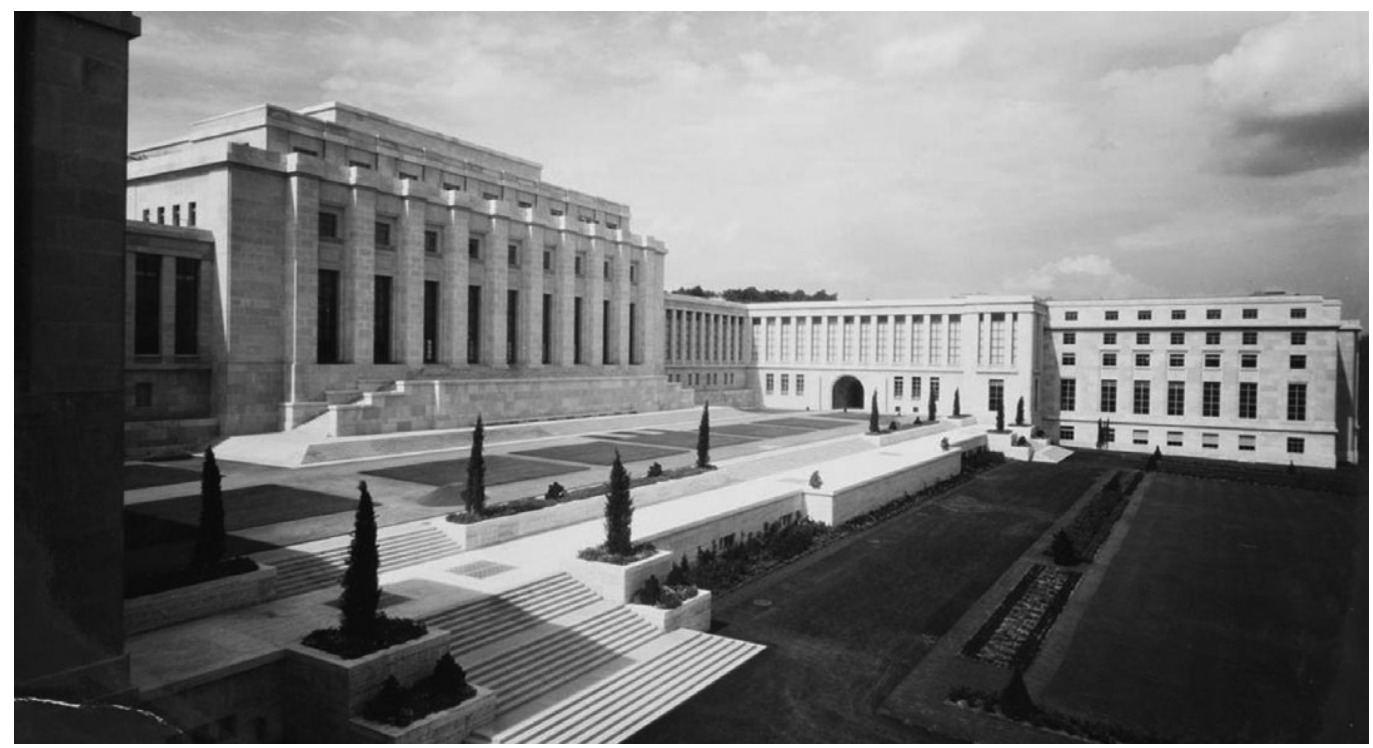

Figure 4. The Palace of Nations after the construction of the cafeteria in 1958 Photo: United Nations $\odot$ United Nations Archives at Geneva.

The Palace's ceremonial architecture, particularly the classicism in its facades, was 'calculated to please the member states', notes historian Catherine Courtiau; ${ }^{101}$ or perhaps more accurately, calculated to please Western European member states. Having been founded at the Palace of Versailles - the archetypal setting of a classical representation of power of European aristocracy-based diplomacy and imperialism - the League's permanent home was to evoke a similar aesthetic. And indeed, politically, the League emerged as an instrument of the great powers that had founded it. ${ }^{102}$ Appeals to a renegotiated idea of international law and sovereignty, and the rights of national groups and colonial peoples were to prove largely hollow. Instead, the Mandate System provided a stopgap to the disrupted colonial sovereignty of the Axis powers without going so far as to grant independence to the colonial inhabitants. ${ }^{103}$ Like the stripped back classicism of the Palace of Nations building, the Mandate System largely took the old standard of civilization and recalibrated it, extending imperial control in a less overt form. ${ }^{104}$ Indeed, speaking in 1919 Lloyd George noted that 'there was no large difference between the principles of the Mandate System and those of the Berlin Conference'. ${ }^{105}$ The League may have been premised upon a new style of international engagement but this was not expressed by adherence to new architectural innovations.

What quickly eventuated, as Meyer and Corbusier had no doubt foreseen, was that conventional design was incapable of producing solutions to accommodate a modern organization. ${ }^{106}$

\footnotetext{
${ }^{101}$ C. Courtiau, 'La Cite Internationale, 1927-1931', in Le Corbusier a Geneve (1987), 53, quoted in ibid.

${ }^{102} \mathrm{M}$. Mazower, Governing the World (2012), at 141.

${ }^{103}$ See W. Bain, Between Anarchy and Society: Trusteeship and the Obligations of Power (2003), at 107.

${ }^{104}$ These colonies and territories were, in the words of Art. 22 of the League Covenant, inhabited by peoples not yet able to stand by themselves under the strenuous conditions of the modern world'. Architect of the scheme, General Jan Smuts, later South African Prime Minister and a key advocate of racial segregation, argued that 'the German colonies in the Pacific and Africa are inhabited by barbarians, who not only cannot possibly govern themselves, but to whom it would be impracticable to apply any ideas of political self-determination in the European sense'. J. C. Smuts, 'The League of Nations: A Practical Suggestion', in D. H. Miller (ed.), The Drafting of the Covenant (1928) Vol. 2, at 29-31.

${ }^{105}$ D. Hall, 'The Trusteeship System', (1947) 24 British Yearbook of International Law 33, at 37.

${ }^{106}$ S. Giedion, 'The League of Nations Competition, 1927: Contemporary Architecture Comes to the Front', in Space, Time, and Architecture (1938), at 445.
} 
The requirements of a complex new entity like the League of Nations, critic Sigfried Giedion argued:

could not be met by schemes whose general outline was determined in advance by the need for a certain type of impressive external appearance ... everything was smothered by the ostentatious exterior, as unsuitable here as plate armour for a man driving a car. ${ }^{107}$

So consumed were the architects by the imperative to fulfil a classical design that they entirely overlooked the need for a more thoughtful technicism, particularly given the building's awkward placement on the lakeside site. The final design was unable to find a way of avoiding extensive terracing of the site, which destroyed its natural contours and left the huge bulk of the Palace perched upon a ridiculously small pediment of lawn'. ${ }^{108}$ Indeed, the building speaks little to its surrounding environment, exuding a sense of isolationist ostentatiousness rather than open diplomacy. Giedion's pronouncement in the Berlin journal Bauwelt in 1927 proved eerily prescient: 'A League of Nations building that ties itself to the ghosts of history is likely to become a haunt of ghosts. ${ }^{\prime 09}$ By the time the structure was completed in 1936 the optimism which had inspired the initial brief was in stark contrast to rising nationalism and the increasingly hopeless view of internationalism. ${ }^{110}$ The League was housed in the Palace for barely three years before the outbreak of the Second World War, during which time the Palace of Nations was virtually deserted due to institutional paralysis.

\section{Modernism's triumph and the International Style: The UN Headquarters NYC 1947-1952}

While the interwar years represented the stalled efforts of internationalism and the ultimate triumph of nationalism, both politically and aesthetically, it can be said that in the years immediately following the Second World War the confluence of internationalism and modernism reached their pinnacle. Multilateralism and sovereign equality were to define the post-1945 international framework, embodied in the UN Charter, a document embodying 'a spirit of give and take, of tolerance for the views and interests of others', ${ }^{111}$ while modernism, seen as ideologically neutral in character and futurist in outlook, was to provide the united front for the new United Nations. ${ }^{112}$ Attitudes towards international law and diplomacy had dramatically shifted, however. For one thing, the new Charter system was prepared to accept the 'realism' of Great Power politics and the limits of legal rules, as reflected in the key position of the five Permanent Members of the Security Council. ${ }^{113}$ A host of new international actors, including the Non-Aligned Movement now also posed serious opposition to Western political dominance. In this climate, most international lawyers, now saw their role as promoting peaceful coexistence and averting conflict through a more conciliary framework of international rules and guidelines. ${ }^{114}$ International legal co-operation 'could not go "against" power-it could only at best enlist power

\footnotetext{
${ }^{107}$ Ibid.

${ }^{108}$ Ibid.

${ }^{109}$ Ibid., at 446.

${ }^{110}$ See M. Koskenniemi, 'The History of International Law, World War I to World War II', in Max Planck Encyclopedia of Public International Law (2011).

${ }^{111}$ H. S. Truman, 'Address in San Francisco at the Closing Session of the United Nations Conference', 26 June 1945, in Public Papers of the Presidents of the United States: Harry S Truman (1945).

${ }^{112}$ Pearson, supra note 99, at 85. As Pearson notes: 'After 1945 Classicism was to bear the taint of both repugnant political ideology and diplomatic failure'.

${ }^{113} \mathrm{M}$. Koskenniemi, 'The History of International Law Since World War II', in Max Planck Encyclopedia of Public International Law (2011).

${ }^{114}$ Ibid.
} 
for its own purposes'. ${ }^{115}$ This new balance of power was reflected not only in the new American setting of the UN, but also in the nationalities of the architectural team selected to design the UN headquarters (Chinese, Russian, Canadian, French, British etc.), which closely mirrored the countries who were to assume the top rung in post-war diplomacy. ${ }^{116}$

In the immediate aftermath of the Second World War, the diplomatic centre of the world had shifted from Geneva to the urban centre of post-war capitalism, New York. Internationalism turned to contemporary efforts of rebranding and marketing to cement its new image as something different from the failed legacy of the League, with advertisements and musical anthems seeking to garner public favour. ${ }^{117}$ It was architecture, however, that was to assert a clean break with the past. In place of the authoritarian and fascist undertones of Classicism and traditional monumental architecture embodied in the Palace of Nations, modernism would be the new currency to convey a revitalized internationalist vision. ${ }^{118}$ Bound up with America's efforts to define its global role as a new superpower that would reinforce the position of the West in the struggle with the Soviet Union, ${ }^{119}$ the New York site was decided in early late 1946 when John D. Rockefeller gifted an 18-acre block on the East River, a district home to slums, stockyards, and slaughterhouses, once known as 'Blood Alley'. ${ }^{120}$ For many the site contained enormous symbolism, a press release declaring that ' $[\mathrm{t}] \mathrm{he} \mathrm{UN}$ skyscraper capital will rise upon a site that in many ways represents all the human, economic and material woes of the world at large'. ${ }^{121}$

There was a clear awareness of the importance of creating an inspiring and symbolic setting for the UN. Commentators expressed the need for the structure to mirror the ambitious program and ideals of the UN: international co-operation, democracy, commonality, and mutual respect. ${ }^{122}$ The structure, argued architect Lewis Mumford, should be 'a paragon of the new order we are in the course of building. ${ }^{123}$ With the memory of the fiasco surrounding the design process for the Palace of Nations still fresh, the decision was made to forego an architectural competition and to form an international design team of architects and engineers from ten countries who would work in unison to complete the project as swiftly as possible. ${ }^{124}$ The make-up of the (all-male) team was both symbolic and pragmatic in its formulation, as it was hoped that the diversity of the team would mean that the design would be the product of a global vision rather than that of one single architect or national architectural tradition. ${ }^{125}$ The decision to appoint Le Corbusier was a symbolically charged nod to the injustices of the League of Nations debacle. Rather than the western European domination seen in previous competitions, moreover, the team included the Brazilian Oscar Niemeyer, Uruguayan Julio Vilamajo, and Chinese architect Liang Sicheng. 'We are a team; the World Team of the UN laying down plans of a world architecture' declared Le Corbusier. ${ }^{126}$ Politics, however, dictated the make-up of the team, led by American architect Wallace Harrison, best known for his work designing the buildings of corporate America. Prominent modernists Walter Gropius and Ludwig Mies van der Rohe were deemed ineligible

\footnotetext{
${ }^{115}$ Ibid.

${ }^{116}$ J. Morris, 'Origins of the United Nations', in T. Weiss and S. Davis (eds.), The Oxford Handbook on the United Nations (2018), 42, at 45.

${ }^{117}$ Mazower, supra note 102, at 266.

${ }^{118}$ Pearson, supra note 99 , at 86.

${ }^{119}$ R. O. Keohane, 'Twenty Years of Institutional Liberalism', (2012) 26(2) International Relations 125, at 127.

${ }^{120}$ Pearson, supra note 99 , at 87.

${ }^{121}$ United Nations World quote in S. Zipp, Manhattan Projects: The Rise and Fall of Urban Renewal in Cold War New York (2010), at 59.

${ }^{122}$ Crinson, supra note 3 , at $184-5$.

${ }^{123}$ L. Mumford, 'A World Centre for the United Nations', (1946) 53 Journal of the Royal Institute of British Architects, at 427-34.

${ }^{124}$ Pearson, supra note 99 , at 100.

${ }^{125}$ Ibid.

${ }^{126}$ Quoted in G. Dudley, A Workshop for Peace: Designing the United Nations Headquarters (1994), at 213.
} 
given their German origins, ${ }^{127}$ although Le Corbusier's alignment with the French far-right in the 1930s and his work as a city planner for the Vichy régime was not held against him.

Modernism, however, had undergone significant changes in the nearly three decades since its inception, mirroring broader geopolitical transformations. While Soviet architects renewed their commitment to the traditionalist forms of 'Stalinist architecture' and its social-political concerns, American architects were eager to move in the opposite direction, framing American efforts of democratization in technological progressive and futuristic terms, but purely as a stylistic idea, thus ensuring it was an aesthetic 'safe for millionaires'. ${ }^{128}$ In this climate, as Crinson notes, modernism became increasingly bound up with concerns of uniformity and cultural homogenization, which 'were seen as compromised by association with grand narratives and teleology, not to speak of colonialism, neo-colonialism, developmentalist policy, and a rampantly globalizing capitalism'. ${ }^{129}$ The tension between a notion of utopian modern architecture as connected an alternative organization of the world, and the more sinister projection of economic dominance and the projection of national interests through the cover of internationalist rhetoric, was to define the immediate post-war period.

These competing strands of modernism were nowhere more prevalent than in the ideological tensions that arose in determining the appropriate symbolism to express the nature of the UN, particularly between the two most prominent members of the design team: Le Corbusier and Niemeyer. Le Corbusier wanted a radically new form of design, one that envisaged the UN at the forefront of a new form of political organization. His vision for the UN was one of a 'world capitol' that would include a centre for research in international law, a world library, and a world museum. ${ }^{130}$ Harrison, however, insisted upon a design which elevated functionality over symbolism. 'The basic problem', he explained, 'is not to symbolize the UN in some highly imaginative design, but to construct a capitol where the world representatives can work efficiently and in comfort'. ${ }^{131}$ The key design issue became the placement of the building's three major structures - the General Assembly, the large Secretariat for the UN's permanent bureaucracy, and the chambers for the three principal UN councils - on the narrow waterfront site. Le Corbusier invoked elements of his League of Nations scheme, integrating the various elements into one structure in order to establish a streamlined continuity. ${ }^{132}$ Niemeyer, however, who in contrast to Le Corbusier's fascist leanings had been convicted on the basis of his membership in Brazil's communist party, proposed pulling the three structures apart in a more abstract fashion. ${ }^{133}$ Emphasizing openness, volumetric abstraction, and freedom from strict symmetry (a clear rejection of classicism), Niemeyer's design would eventually form the basis of the design approved by the General Assembly in late 1947 (Figure 5 below).

The result could not have been more different than the Palace of Nations constructed only 20 years before. From the neo-classical ashes of the League rose a strikingly abstract and geometric tower, largely indecipherable from the towering Manhattan skyscrapers that surround it. The building's focal point is the 39-story high-rise Secretariat tower clad in aluminium, glass, and marble, reflecting the blue-green colour of the Hudson river, which looms over the complex. Below sits the great curved General Assembly Hall with its low, sculpted form, matt cream colour, windowless facades, and domed roof. On the opposite side sits another low, rather discreet trapezoidal building which houses the council rooms. The buildings are connected by means of corridors, stairs, and galleries, yet they appear at a distance to be isolated from one another. The effect of the spatial relationship between the three buildings, particularly when one stands in the central square, is a tension between unity and isolation. The structure's stark proportions and

\footnotetext{
${ }^{127}$ E. P. Nash, Manhattan Skyscrapers (1999), at 99.

${ }^{128}$ J. Ockman, Architecture Culture, 1943-1968: A Documentary Anthology (1993), at 13.

${ }^{129}$ Ibid., at 11 , also $197-8$.

${ }^{130}$ Pearson, supra note 99 , at 86.

${ }^{131}$ Quoted in Dudley, supra note 126, at 32.

${ }^{132}$ Pearson, supra note 99 , at 88.

${ }^{133}$ Ibid., at 92 .
} 
Figure 5. The United Nations Headquarters, New York, 1952 Photo: United Nations (c) United Nations Multimedia Library.

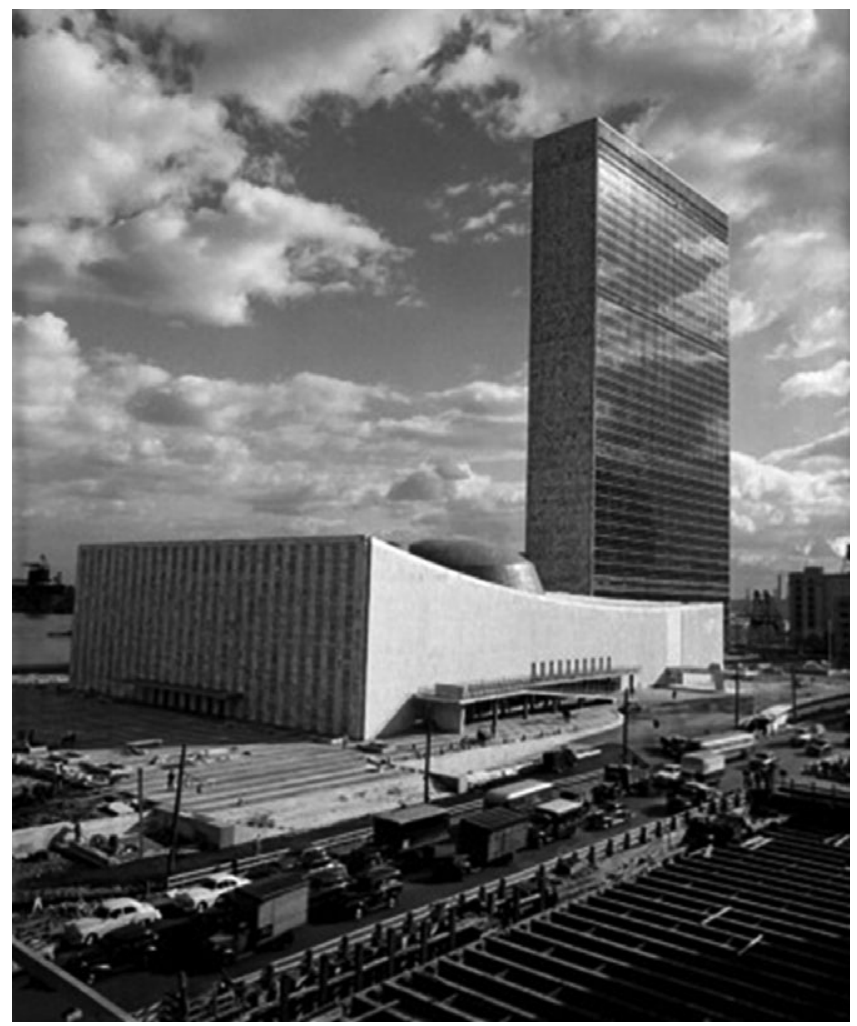

asymmetrical geometry serve the modernist vision of progress and innovation met with grandiosity and functionalism, while the ban on any kind of ornamentation or historical references prevented any outward statement of culture or architectural tradition. Touches of classicism are still evident, however, such as the large dome of the Assembly building (an addition insisted upon by the US Government, evoking its own domes of Washington and other state capitol buildings), as well as the use of white Portland stone on the external cladding of the Assembly building. ${ }^{134}$ The interiors are perhaps the most striking aspect of the design. The Assembly Hall, with its sweeping proportions and circular design, illuminated by the light of the striking dome, provides a grand statement on the function of the UN. The Hall originally contained only 71 seats ( 20 in addition to the UN's then 51 members) and was altered in 1980 to increase capacity to accommodate the new memberships. Oscar Schachter, who was consulted by the architects regarding the design of the Assembly Hall, noted in 1997 that his failure to predict imminent rise of new member states following the fall of colonialism had been one of his 'main mistakes' as an international lawyer. ${ }^{135}$ The use of mid-century modernist aesthetics, designed by Scandinavian modernists, provide a light, clean atmosphere in the meeting rooms and common areas, while the glass clad foyers, which provide multiple viewing points into the assembly hall suggest an open and participatory diplomacy. Rather than the older notions of symbolic art that had been deployed at the Palace of Nations and the Palace of Labour, attempts to achieve a synthetic unity between art and architecture are seen in the abstract, non-figurative and non-narrative art and sculpture that fill the building, including murals by Ferdinand Leger, Marc Chagall, Per Krohg, and Barbara Hepworth. There is also a wide selection of indigenous art and decoration. Then Secretary

\footnotetext{
${ }^{134}$ Dudley, supra note 126 , at 214.

${ }^{135 ‘}$ A Conversation with Oscar Schachter', in ASIL Proceedings (1997), at 344.
} 
General Dag Hammarskjold frequently spoke of the parallels between the ideals of modern art and the political work of the United Nations, noting in 1954

in ... aiming towards that world of order which now more than ever seems to be the only alternative to disruption and disaster, we have to approach our task in the spirit which animates the modern artist. We have to tackle our problems without the armour of inherited convictions or set formulas ... ${ }^{136}$

The structure was met with a mixed response. Some saw it as a triumph of technology, a suitably visionary solution to the problem of designing large-scale public architecture in the post-war world. Robert A.M. Stern described it as 'the long-awaited, triumphant realization of interwarera Modernist architecture and urbanism' ${ }^{137}$ Many criticized its placement in a commercial centre, its lack of green spaces, and the volume of the structures which seemed to overwhelm its occupants with abstract grandiosity. ${ }^{138}$ Frank Lloyd Wright described it as a 'super-crate, to ship a fiasco to hell' and 'a sinister emblem for world power' ${ }^{139}$ Observing that the Secretariat tower was still nothing more than an office building, Mumford argued that the skyscraper would forever carry the message abroad that the UN was identified with American values globalized. ${ }^{140}$ And indeed, as much as the League of Nations had been formed and dominated by European members deciding on a settlement after the war, so the UN's early mandate was dominated by EuroAmerican concerns and by the continuation of colonial development policies. ${ }^{141}$

By the end of the decade the appeal to modernism as symbolic of international unity had also begun to run out of steam. The idea of stripping away the particular in favour of a merger of international identities in an act of unity of design prefaced on 'objectivity' and 'functionality' largely replaced one idea of false universalism with another. ${ }^{142}$ The development of a new 'universal' aesthetic language - 'the International Style' - which was said to transcend the nation and national identities, but which was largely modelled on a European aesthetic and Eurocentric concerns, mirrors international law's insistence upon a particular vision of the 'International'- one that saw the seamless integration of a European legal tradition into a generalized representation of universalism. By the late 1960s there was the sense that the austerity, formulaic uniformity and abstraction of modernism had become a simulacrum of western globalization and homogenization of cultures. ${ }^{143}$ In the words of architect James L Nagle: 'You got off an airplane in the 1970s, and you didn't know where you were.' ${ }^{\text {'14 }}$ As postmodernism took hold, there was a reconsideration of the concept of culture in a manner that could accept diversity rather than insist on uniformity. ${ }^{145}$ The move towards post-modernist expression in many ways mirrors the broader shifts in international law in the late 1960s and 70s, particularly amongst newly independent states. Having harnessed the 'new international law' to secure a legal basis for decolonization, they now adapted and moulded its tenants to assert their independence, reform the inequalities of the global economic system and resist patterns of Western domination. ${ }^{146}$ Similarly, in reconstructing

\footnotetext{
${ }^{136}$ D. Hammarskjold as quoted in B. Urquhart, Hammarskjold (1972), at 48.

${ }^{137}$ R. Stern, A. M. Mellins and D. Fishman (eds.), New York 1960: Architecture and Urbanism between the Second World War and the Bicentennial (1997), at 617.

${ }^{138}$ Pearson, supra note 99 , at 88.

${ }^{139} \mathrm{~F}$. Lloyd-Wright quoted in (1947) Journal of the American Institute of Architects, at 158.

${ }^{140}$ L. Mumford, 'United Nations Assembly', in T. Hughes and A. Hughes (eds.), Lewis Mumford (1956), at 37.

${ }^{141}$ See G. Sluga, 'UNESCO and the (One) World of Julian Huxley', (2010) 21 Journal of World History 393, at 408-10.

${ }^{142}$ See K. Eggener, 'Nationalism, Internationalism and the "Naturalisation" of Modern Architecture in the United States, 1925-1940', (2006) 8(3) National Identities: 'Space, Time: Indentity' 243.

${ }^{143}$ Crinson, supra note 3, at 186-8.

${ }^{144}$ Quoted in B. Kamin, 'Adding up the other Chicago Seven', Chicago Tribune, 2 October 2005.

${ }^{145}$ J. Clifford, The Predicament of Culture, Twentieth-Century Ethnography, Literature, and Art (1988), 234.

${ }^{146}$ See D. Otto, 'Subalternity and International Law: The Problems of Global Community and the Incommensurability of Difference', (1996) 5 Social \& Legal Studies 337; F. E. Snyder and S. Sathirathai (eds.), Third World Attitudes Towards
} 
their post-colonial identities, architects from North Africa, Latin America and South Asia adapted the technical innovations of modernism and re-formed it to adopt their own causes and principles, which challenged the universality presumptions of European modernism. ${ }^{147}$ By 1978, Paul Goldberger called the UN headquarters 'a symbol not of progress but of conservatism'. ${ }^{148}$

\section{Conclusion}

While these architectural episodes provide a brief introduction to international law's relationship to its built spaces, they also reveal glimpses of the contingent and changing idea and images of internationalism and international law in the early half of the twentieth century. If law is 'constructive of social realities rather than merely reflective of them', as Clifford Geertz once asserted, than law's relationship to the haptic and aesthetic organization of space is equally as enmeshed. ${ }^{149}$ In this account I have sought to suggest that the architectural design of the structures of international law reveals something precise about how ideas of international legal order and authority are reproduced and expressed through time, beyond the monolithic representations of international institutions produced by their mandates and by the outside perspectives that focus only on the content of their documents and public statements. Viewed through the lens of the architectural design, ideas surrounding the role of international legal institutions were subject to constant evolution and reinvention, spawning multiple and varied universes and competing visions of international legal order, as a result of both internal and external pressures. Beyond this, however, I have also sought to suggest that the tensions that arose in the attempts by modern architects to break free of the nation state through the development of an international visual language, in many ways mirror those present in the development of an international legal and political consciousness beyond national identity during this time; an anxiety that remains incredibly prescient in contemporary international legal discourse. ${ }^{150}$ What this brief sketch seeks to underline, is that the aesthetic and functional frames of international law communicated by these structures are consciously or not - far from neutral and should prompt us to consider how they and other structures affect our understanding about international law and the identity of the international community. There is still much territory left to explore.

\footnotetext{
International Law: An Introduction (1987); M. Salomon, 'From NIEO to Now and the Unfinishable Story of Economic Justice', (2013) 62 International and Comparative Law Quarterly 31.

${ }^{147}$ See M. Eleb, 'An Alternative to Functionalist Universalism: Ecochard, Candilid and ATBAT-Afrique', in S. Goldhagen and R. Legault (eds.) Anxious Modernisms: Experimentation in Postwar Architectural Culture (2000).

${ }^{148} \mathrm{P}$. Goldberger, The City Observed, New York: A Guide to the Architecture of Manhattan (1979).

${ }^{149}$ See C. Geertz, 'Local Knowledge: Fact and Law in Comparative Perspective', in Local Knowledge: Further Essays in Interpretive Anthropology (1983),167, at 232.

${ }^{150}$ See M. Koskenniemi, 'The Case for Comparative International Law', (2009) 20(1) Finnish Yearbook of International Law 1; A. Robert, Is International Law International? (2017); M. Bak McKenna, 'Decentering the Universal: Comparative Law as Decolonizing Critique', (2018) 12(1) ESIL Conference Paper Series.
}

Cite this article: Bak McKenna M (2021). Designing for international law: The architecture of international organizations 1922-1952. Leiden Journal of International Law 34, 1-22. https://doi.org/10.1017/S092215652000059X 